\title{
The Influence of Ethnic Power Sharing Mechanisms on the Functioning of Parliaments in the Western Balkans
}

\section{Zsolt SZABÓ}

\author{
Department of Constitutional Law, Faculty of Law, Károli Gáspár University of the Reformed Church \\ in Hungary \\ Alkotmányjogi Tanszék, Állam- és Jogtudományi Kar, Károli Gáspár Református Egyetem \\ Kálvin Square 9, 1091 Budapest, Hungary \\ szabo.zsolt@kre.hu
}

\section{Introduction}

This article reflects the main findings of a comparative analysis of the procedures and practices of parliaments in Western Balkans countries (Albania, Bosnia and Herzegovina, Kosovo, F. Y. R. of Macedonia, ${ }^{1}$ Montenegro, Serbia) published in a monograph in Hungarian. ${ }^{2}$ The current paper focuses of the consequences of the complex ethnic landscape in government structures of the countries (especially the delicate compensatory procedures for ethnic representation and ethnic balance), and the constitutional evolution and history of parliaments in the region. The analysis of the contemporary legal environment of the nine parliaments of the six countries (central and autonomous, local) shows differences and similarities as well in the various parliamentary functions (the work of plenary sessions and parliamentary committees, legislative agenda setting, legislative procedure, legislative scrutiny, the legal status of MPs, legislative transparency). Data on the below described parliamentary practice was gathered mostly by direct correspondence with the relevant parliamentary services as well as by internet-based research.

The term "Western Balkans" is not a historical one; it is a geographical and geopolitical term of recent coinage. It has entered public circulation from the official parlance of the European Union, which often treats them as a homogeneous group. With one exception (Albania), the countries that belong to it, used to be countries of ex-Yugoslavia. These countries also share a common historical heritage as being part of the Ottoman Empire, and gaining independence with help of external powers only between 1878 and 1912, then being part of the socialist block after WWII. Today they are all surrounded by member states of the European Union, waiting for their accession.

\section{The Starting Point: Delayed Consolidation and Ethnic-Based Politics in Western Balkans}

After the settlement of the violent conflicts of the 1990s (wars in Bosnia and Herzegovina in 1992-1995, conflict in Kosovo between 1998 and 1999) and also the conflict between

1 Hereinafter: Macedonia

2 SZABÓ, Zsolt: A Nyugat-Balkán parlamentjei, Budapest 2016. 
Albanians and Macedonians in 2001 (which almost escalated into a civil war) the region set out along constitutional consolidation, albeit with a delay. In spite of the massive assistance and expertise provided by international donors, there is still much to be done in the field of rule of law, ${ }^{3}$ even if it certainly has struck some roots in the region. Ethnic-based politics is still a strong group-forming factor even if militant nationalism has lost its appeal to a considerable part of the voters, who are tired of the ethnic conflicts. Violent ethnic conflicts have been replaced by confrontation in the political sphere. The European Union propagates the model of a democratic state in which several nationalities coexist because the EU considers it as the only viable alternative to separatist and nationalist endeavours. Attractive as that model is in principle, it is extremely difficult to implement it by applying constitutional regulation. A regime based on ethnic power-sharing - one that gives preference to the interests of certain ethnic groups - can only be built to the detriment of a democratic state (see for instance, the nationality quotas and vetoes in Bosnia and Herzegovina and Kosovo).

The ethnic composition influences the daily life of individuals and the functioning of the states heavily. Public discourse is dominated by ethnic issues ${ }^{4}$ even in those countries of the region that are relatively homogeneous ethnically. As in multi-ethnic societies democracy and equality before the law might become distorted, constitutional provisions should affirm the political representation of the minorities or seek a kind of ethnic equilibrium. As for the first requirement, examples can be found in Kosovo and Macedonia, as for the latter one, there are examples in Bosnia and Herzegovina. In Western Europe (Belgium, Switzerland and Northern Ireland) the following typical solutions can be seen: arrangements to determine the composition of public authorities (quotas and pre-reserved positions), the rules of decision-making (dual vote) and compensatory procedures (right of veto and the so-called "vital national interest" procedure). In the Western Balkan region there are examples of employing all those solutions simultaneously, yet with a lack of mutual trust and confidence in the ethnic groups towards each other's keeping the rules of the game. Take the example of Bosnia and Herzegovina: its public law system is based on ethnic balance instead of democratic legitimacy. Often however such institutional formulas preserve rather than reduce inter-ethnic conflicts, and they encourage ethnic-based interest representation instead of democratic, rule-of-law solutions. ${ }^{5}$ In an ideal case such institutionalized ethnicity ${ }^{6}$ solutions would be the consequences rather than the basis for the peaceful

3 MENDELSKI, Martin: Where does the European Union make a difference? Rule of law development in the Western Balkans and beyond, in: European Integration and Transformation in the Western Balkans. Europeanization or business as usual?, ELBASANI, Arolda (ed.), London 2013, 101-118.

4 STOJANOVIĆ, Nenad-HODŽIĆ, Edin: Introduction: Ethnocracy at the Heart of Europe, in: Ethnopolitics, 14, 2015, 4, 382-389.

5 Due to the previously intense ethnic conflicts in the country, the High Representative for Bosnia and Herzegovina (HR), along with the Office of the High Representative (OHR), was created immediately after the Dayton Peace Agreement in 1995 in order to oversee the civilian implementation of this agreement. The HR was given the authority to impose laws necessary for the reintegration of Bosnia and Herzegovina into a functional state, as a precondition for European integration and integration into world organizations. OHR had a very important role in the process of drafting the proposals of the majority of laws, particularly those relating to election rules, reform of judicial power and economic reform. Since 2006, the HR has used practically none of his powers to impose laws and other regulations, in an attempt to transfer the ownership of reforms to domestic policy makers.

6 BIEBER, Florian: Institutionalizing Ethnicity in the Western Balkans. Managing Change in Deeply Divided Societies, ECMI Working Paper No. 19, Flensburg 2004. 
coexistence of ethnic groups and they would be conceived as voluntary behavioural patterns rather than mandatory rules. As an EU Report stated about the Federation of Bosnia and Herzegovina: "legislative work is adversely affected by intransigent and ethnically oriented positions taken by the country's political leaders." political field, a clear coalition and a stable majority in parliament are often missing, and the cooperation between parliament and government is insufficient. In some cases, laws adopted by the government were later blocked in parliament by the same political actors from the government coalition. In addition, no proper mechanism exists in the legislative process for the coordination between the State parliament and the Entity parliaments. ${ }^{8}$ According to Priebe, ${ }^{9}$ besides questions of economic constitutionality, the region's most important and urgent tasks to be fulfilled in terms of constitutionality are justice system and parliamentary structures.

The status of political parties is not fully settled in the region, and they have a powerful influence on the operation of institutions and nominating public appointees. The financing of parties is opaque, and the institutions of democracy tend to be formal or even downright dysfunctional. Although the relevant rules look impressive on paper, often the institutions work ineffectively. That doubly applies to the work of parliaments: it is quite common that opposition MPs walk out from or boycott legislative sittings; and occasionally brawls occur or even tear gas is used (Kosovo). The culture of political compromise is underdeveloped and aggressive reflexes dominate daily political strife. There are hardly any parliaments in the region where the opposition has not declared a full boycott of parliamentary work yet or where the work of parliament has not been paralysed by a political stalemate.

After elections, the formation of a new parliament and government is often delayed by political wrangling, which can temporarily idle public institutions. Due to recurrent crises and political stalemates - which are consequences of the instability of the political system - the voters of the region have grown sceptical about the ability to make an impact on the political scene, which is dominated by the region's strongmen. In contrast to the high voter turnout that marked the undemocratic elections before the political transition, nowadays electoral turnout is very low.

\section{The Evolution and Conditions of Parliamentarism}

Independent statehood in the Western Balkans has the longest history in Serbia and Montenegro. The independence of the two countries was guaranteed by the Congress of Berlin of 1878, though Serbia had attained de facto independence before. Those two countries are still more stable than the rest of region. Macedonia also used to be stable but has been

7 Bosnia and Herzegovina 2009 Progress Report, Commission of the European Communities, document SEC (2009) 1338, Brussels 2009, online: https://ec.europa.eu/neighbourhood-enlargement/sites/near/files/ pdf/key_ documents/2009/ba_rapport_2009_en.pdf.

8 Bosnia and Herzegovina 2010 Progress Report, European Commission, document SEC (2010) 1331, Brussels 2010, online: https://ec.europa.eu/neighbourhood-enlargement/sites/near/files/pdf/key_documents/2010/ package/ba_rapport_2010_en.pdf.

9 PRIEBE, Reinhard: Beitrittsperspektive und Verfassungsreformen in den Ländern des Westlichen Balkans, in: Europarecht, Vol. 3, 2008, 310-319. 
beset by signs of instability recently. Historically speaking, Macedonia obtained independence for the first time as a member republic of ex-Yugoslavia, yet 1991 it left the federation peacefully and become a fully sovereign entity. Though the Macedonian-Albanian armed conflict of 2001 interrupted Macedonia's course towards stabilization and European integration, with time it could settle its internal conflicts and avoid a protracted crisis. Kosovo and Bosnia and Herzegovina reached independence for the first time in their history with the support of the international community amidst bloody wars in the late 1990s. They still need international assistance for exercising state functions and cannot be seen as sovereign states. Serious ethnic conflicts are weakening the operation of their state authorities. Albania is following a course of its own in many respects. Although it has a history of a hundred years, it lacks robust democratic traditions and its passage to parliamentary democracy has been slow.

Throughout their history countries of the Western Balkans have often been subjected to foreign interventions, their sovereignty was limited and, as a consequence, constitutions were often forced on them from outside. Following the suzerainty of the Ottoman Empire, the region came under the sway of European Great Powers at the end of the $19^{\text {th }}$ century. As early as the $19^{\text {th }}$ century the Ottoman Empire forced a constitution on Serbia. There was a strong external pressure (of the European Union) both when the constitution of Bosnia and Herzegovina was framed in 1995 and when the federation of Serbia and Montenegro adopted its constitution in 2003. Some observers say that Kosovo's Constitutional Framework for Provisional Government (2001) was also de facto adopted under external pressure, and the constitution that Albania adopted in 1998 was also framed with foreign (chiefly US) assistance. Some domestic political forces in the region urge the comeback of forced constitutions - again - by external powers, for they see it as the only way to get out from the stalemate. ${ }^{10}$

In the socialist regime, these parliaments had a predominantly formal role in the state decision-making process, legitimating the system with their existence. Other political organs were the main formal decision-making institutions, the more important political decisions were made informally by the socialist party. Parliaments, without any opposition, convened only occasionally and approved, without any substantial debate, only the most important pieces of legislation. These countries are now in the aftermath of the transition into democracy, they have all made considerable improvements on the way to parliamentarism, having introduced new parliamentary procedures i.a. for legislation. After the split of federal Yugoslavia, its former member state parliaments adopted the federal law, incorporating it as national law in their own legal systems - a process that sometimes is called 'nostrification'. After this initial phase, they started to modify the nostrified former federal law, adjusting it to their different needs, which led to a disintegration of the previously common Yugoslavian law. This adjustment or modification procedure put a major legislative burden to parliaments, just like todays' procedure towards adopting the EU acquis.

Referendums - practically the only acts of direct democracy in the region - were instrumental in securing independence throughout the region - this is another common feature of

10 BIEBER, Florian: Power Sharing and International Intervention: Overcoming the Post-Conflict Legacy in Bosnia and Herzegovina, in: Settling Self-determination Disputes: Complex Power-sharing in Theory and Practice, WELLER, Marc - METZGER, Barbara (eds.), Leiden - Boston 2008, 193-241. 
the country group. Independence was achieved by referendum in Bosnia and Herzegovina (1992), Macedonia (1991), Kosovo (1991) and Montenegro (2006). As for the approval of constitutions, such referendums were only held in Serbia and Albania. In Serbia both in 1990 and 2006 referendums were held to confirm the constitution - preceded by campaigns replete with political slogans of separatism. The first referendum was to confirm the constitution brokered by Slobodan Miloševic and the second one to approve Serbia's current constitution. In Albania referendums were held about the constitution in 1994 and 1998 but only the latter one was valid.

Though the countries of the region differ in religious and ethnic background, the present-day constitutional setup of the six countries has plenty of similarities. Each of them has a parliamentary form of government. The executive power - the government - is accountable to the parliament, and it needs the parliament's uninterrupted political support. The government and its head are elected by the parliament. It is in the competence of the parliament to adopt the constitution, (though in some of the countries of the region the constitution needs popular approval) and the work of almost every parliament in the region is subject to the scrutiny of an independent Constitutional Court. The system of government is of multi-level in Serbia (because of the autonomy of Vojvodina) and in Bosnia and Herzegovina (where there are the so-called Entities) yet in the other countries it is unitary. By the end of the 2000s the electoral system had become fully proportional in each country of the Western Balkans. In Macedonia and Albania there are regional lists (six electoral districts in the first and twelve in the latter) but in the other countries there are national lists. The electoral system does not include preferential elements in any countries. The political parties play a dominant role in nominating candidates, and the voters cast their ballot on lists compiled by the parties. The voters have no other way to express their preferences. (In this respect only Kosovo's electoral system differs.)

Apart from differences in the ethnic compensatory procedures, these countries differ mainly in the status of the head of state. The head of state is directly elected in Serbia, Montenegro, and the Republika Srpska [Bosnian Serb Republic] within Bosnia and Herzegovina. (The collective Presidency of Bosnia and Herzegovina is also elected directly by the population.) The presidents' term is five years, save Bosnia and Herzegovina where it is four years. In the rest of the countries the president is elected by the parliament. Apart from differences in the election of presidents, there is no significant difference in the powers of the presidents: they have a restricted right of veto in their dealings with the parliaments. (Such veto may be exercised just once and within a short period of time.) The president may not exercise a political veto (that is to say, sending a law back to parliament for reconsideration) only in Bosnia and Herzegovina. To illustrate the weakness of such a right of veto: in Albania and Macedonia laws that have been enacted with a qualified majority may not be sent back to parliament at all. In Kosovo and Montenegro the parliament may adopt a rejected law if it wins the same majority as before. In Albania, Macedonia and Serbia the parliament may adopt a rejected law if it wins absolute majority instead of simple majority.

The Western Balkans has a high number of parliaments - and of ethnic groups. The six countries have a total of ten parliaments (including the two Entity parliaments and the Brcko District Assembly in Bosnia and Herzegovina and the National Assembly of Vojvodina in Serbia) and twelve legislative chambers - and that if we do not consider the par- 
liament each of the ten cantons of the Federation of Bosnia and Herzegovina. The heavy presence of representatives of the international community still restricts the elbow room of the parliament each of Kosovo and Bosnia and Herzegovina - even if to a decreasing degree.

European integration features high on the long-term agenda of each of the countries concerned. Fast-track legislative procedures are gaining ever higher currency in the course of approximating national legislation to European Union law. As Bosnia and Herzegovina is a multi-level state, the powers needed for the transposition of the acquis communautaire are divided among the various levels of decision-making. Because there is hardly any dayto-day cooperation among those levels (state, entities and cantons), the process of Bosnia and Herzegovina's joining the EU is moving at snail's pace.

\section{A Brief Comparative Analysis of Parliamentary Procedure and Parliamentary Functions}

As a rule in the Western Balkans the parliamentary rules and procedures are based on the constitution, the parliamentary Rules of Procedure and, in some countries, a separate law on the parliament. Due also to the shared historical and linguistic roots, the rules of parliamentary procedure include many shared elements. There are similarities in the relevant regulations of Albania and Kosovo; Serbia and Montenegro. As for Montenegro, its regulations are similar to those of the Bosnian Serb Republic and, in part, to Macedonia. In some respects the solutions applied in Kosovo differ from those of the other parliaments (though there are similarities in them with fraternal Albania). As the international community has been playing an important role in the region, there are many foreign solutions in the newly framed constitutions. The Albanian constitution also includes several foreign elements due to similar causes. The regulations in Serbia, Montenegro and Macedonia are relatively settled and integral.

Most of these legal sources comply with the principles of democracy and the rule of law yet certain shortcomings can be identified (as for instance, in limiting the free mandate in Serbia, or ethnocratic phenomena in Bosnia and Herzegovina), which have been repeatedly discussed and criticized in documents of the Venice Commission of the Council of Europe. Although the Rules of Procedure provide an appropriate framework for the work of parliaments, they tend to be too detailed and might render parliaments' work too complicated, which can be a hindrance. In several countries of the region the rules of administrative procedure, finance and human resources apply to each and every state agency, including the parliament, which is encroachment on parliamentary autonomy.

Out of the six countries, five have unicameral parliaments (Albania, Kosovo, Macedonia, Montenegro, and Serbia). Compared to these countries, Bosnia and Herzegovina is unique in many aspects. It is a state with a highly complex structure, composed of two main legislative levels, firstly the parliaments of the two entities (Federation of Bosnia and Herzegovina, and Republika Srpska) and secondly a state level legislative, the Parliament of Bosnia and Herzegovina. ${ }^{11}$ The Federation consists of ten cantons with cantonal

11 In Bosnia and Herzegovina also a fourth parliament exists: the Brčko District Assembly (Skupština Brčko dis- 
parliaments that all hold certain legislative powers; the cantons remain out of the scope of this paper. The Parliament of the Federation is a bicameral legislative body, while the Republika Srpska Parliament has only one chamber. ${ }^{12}$ All parliaments of the region are elected for a four year term.

The number of members of parliament (MPs) is highest in Serbia (250), the largest country of the group in terms of population and territory. In the other countries this number varies between 81 and 140. Serbia used to be first also in terms of the number of standing committees (30) until 2012, when this number was reduced to 20 . The number of committees shows a wide range from 9 to 26 in the various parliaments. The number of committees in Bosnia and Herzegovina parliaments is very high, especially in the Federation (26 in the House of Representatives and 19 in the House of Peoples) and in Republika Srpska (20), with regard to the total number of MPs. As far as the composition of committees is concerned, parliamentary groups are proportionally represented in committees in all countries of the region. Committees' significance is constantly increasing, the scope of their competencies is widening, regardless of their number, organizational model or size. However, greater importance is often attached to the plenum session performance than to the essential, professional debate that should take place at the level of the competent committees. ${ }^{13}$ Most parliamentary committees still play a weak, often formal role.

The forums for daily parliamentary political bargaining and establishing the parliamentary agenda are in place and they are crucial for planning the Standing Orders for the plenary sittings of parliaments. In Albania and Kosovo the parliamentary presidency consists of the speaker and the deputy speakers but in the other parliaments the heads of the parliamentary groups of parties (parliamentary factions) may also sit on and vote during the sessions of the parliamentary presidency. Such a permanent forum is, de jure, missing in Macedonia but there is a similar, ad hoc, body that is in session almost continuously. The parliamentary committees divide work among themselves according to fields of specialization but the parliaments vary in the number of committees. There are rules in place to regulate the order of plenary sessions and committee work, and the Standing Orders guarantee opposition MPs the right to make contributions.

Law-making ${ }^{14}$ accounts for the bulk of parliamentary output - by comparison, time and energy devoted to legislative scrutiny is negligible. The most common proponent is the government (the average share of government's proposals is between 45 and $75 \%$ in the region). Except for Albania, also the president of the state may submit a legislative propos-

trikta) is a unicameral legislative body of some eighty thousand citizens around the town of Brčko, and at the same time it is a municipal council.

12 Although the RS parliament is unicameral, some control functions of an upper house are vested in the Council of Peoples, which exercises its power to protect the vital national interests of the constituent peoples, as outlined in the Republika Srpska constitution. The Council does not participate in the law-making process, but controls laws, regulations and legal acts previously adopted in the National Assembly for the purpose of defining whether an adopted law, regulation or other legal act violates any vital national interest of the constituent peoples.

13 PENEV, Slavica (ed.): Improving the process of economic reform legislation in Western Balkan countries, OECD Investment Compact for South East Europe, Belgrade 2009, 23.

14 For a detailed description of the legislative process in the Western Balkans parliaments see SZABÓ, Zsolt: The Parliamentary Legislative Process in the Accession Countries of the Western Balkans, in: Jahrbuch für Ostrecht, Vol. 2, 2015, 375-418. 
al to parliament. MPs may also propose bills. Kosovo is the only state where one MP alone cannot propose legislation, only together with five other fellow MPs. In Macedonia and Serbia, if a group of MPs proposes a law, one of them is appointed as the representative of the initiators.

In Macedonia, Serbia, and Bosnia and Herzegovina, the share of government proposals hardly exceeds the number of proposals by other proponents, in some years it is even lower. Private Member's Bills - as a rule - are important when the government machinery is temporarily not working for some reason. Bills introduced by MPs of the opposition are rare because opposition MPs have few resources, and their bills hardly ever make it to the plenary sessions, let alone to the final vote. In Bosnia and Herzegovina, it often happens that the government is unable to act because of an internal crisis or conflicts between its members. In such a case, there is either no proposing activity, or a proposal might originate from among the MPs.

Amendments to existing laws are always made on a 'one by one' basis in all parliaments of the region: one law can contain amendments to only one law in force. The amendment of several laws at one time is not foreseen. In Albania and Macedonia, there is a theoretical possibility for multiple amendments, but it is not used in practice. In Serbia, it is possible to cancel several laws with one legislative proposal at a time whereas multiple amendments are not possible. In practice, mutually interconnected amendments are considered in a joint parliamentary debate, but formally remain separate bills, subject to separate voting. Apart from the formal legislative proposal procedure, the informal initiative for future legislation by the civil or local society is also regulated in a few countries (Bosnia and Herzegovina, Macedonia). This means that instead of an elaborated legislative proposal with a normative text, stakeholders (individuals, groups, organizations) may submit a concept for future legislation. The decision whether and how the follow-up on the initiative will take place, is entirely in the hand of the parliament.

In all these countries, the government is to be asked for an ex-ante opinion on other proponents' legislative proposals. This means that the executive branch, based on its expertise, is involved in evaluating proposals submitted to the legislative. However, it needs to be further assessed to what extent the opinion of the government service needs to be taken into account and whether this mechanism infringes the parliamentary autonomy and the principle of the separation of powers. Due to its special expertise, government's involvement is especially significant in EU-related issues in the whole region.

The number of proposed bills is significantly higher in Macedonia than in the other countries. In 2011, e.g., more than 700 bills were proposed. However, many (in some years more than a half) of these legislative proposals aim at short modifications of existing legislation, such as adding or changing just a few words in a law, often related to recently adopted laws. Local actors complain that they are often overburdened at short notice with a flood of legislative proposals, some of them detailed and complex, so that they lack sufficient time to act on them properly. ${ }^{15}$ The legislative proposing activity is also relatively high in Serbia. The number of proposals is lowest in parliaments of Bosnia and Herzegovina. One possible reason for that is the separation of competences between the state level and the

15 PENEV, 62. 
entities. The inactivity of the government due to internal conflicts explains this situation. Law-making is the slowest in the parliament each of Bosnia and Herzegovina and the Federation of Bosnia and Herzegovina (with adoption times amounting to more than a year) because lengthy time-limits are set for each stage of lawmaking and parliamentary sittings are far apart.

As a consequence of political and ethnic conflicts, legislative work is often halted or slowed down. Often bills are not appropriately prepared, which is evidenced by repeated amendments - occasionally even of laws adopted just a little while before. As for adopting bills, the rule of thumb is decision by simple majority. When a stronger majority is required, it is absolute majority. On very few occasions a two-thirds or three-fifths majority is prescribed. As far as the legislative procedure is concerned, the first step after the submission of the bill, in all six countries, is the committee stage, which is followed by the plenum discussion, based on the bill and on the committee's report (often presented by a rapporteur). However, the details of the procedure vary depending on whether there is a second committee round and a second, eventually third plenum stage. The working calendar does not always allow enough time to standing committees for a proper review and for public hearings on draft laws, which, as a result, are often adopted in an expedited manner potentially to the detriment of quality. ${ }^{16}$

A special phenomenon of the parliaments in the entity parliaments of Bosnia and Herzegovina is that the procedure falls into two parts: the in-principle-vote on the draft law at the end of the general debate interrupts the legislative procedure. As a consequence, a distinction is made between the notions of a 'draft law' and a 'law proposal'. The 'draft law' procedure is the first reading referred to as the 'draft phase', which again - upon the decision of the plenum - can be divided into two phases: the general proceeding about the necessity and the principles of legislation, and the proceeding on the details of the exact legal solutions. The plenary session may accept suggestions to develop the draft law, or it may refer the draft to a public or professional debate, yet the referral is not mandatory. After the deliberation and vote on the draft law, the proponent has the possibility to make changes and has the duty to submit the law proposal within six months. The obvious aim is that the proponent has the chance to rewrite his bill if arguments of parliamentary debate or public and professional debates convince him. However, it often happens that there is no significant difference between the draft and the proposal. This is a technique inherited from the socialist era, ${ }^{17}$ which slows down the procedure unreasonably. It violates the principle of the separation of powers that, once a bill has been submitted, parliament's leading role is not enforced in parliament. In other parliaments, the procedure consists of two stages (general debate - detailed debate) as well, however, they are not separated from each other by such a clear closure, but rather interconnected: the vote in general opens the second, detailed phase.

The quality of legislative work is compromised by the fact that it is not required to set to

16 Albania 2012 Progress Report, European Commision, document SWD (2012) 334 final, Brussels 2012, online: https://ec.europa.eu/neighbourhood-enlargement/sites/near/files/pdf/key_documents/2012/package/ al_rapport_2012_en.pdf.

17 JOGAN, Savin: Some Specific Elements Concerning the Legislative Process of the S. F. R. of Yugoslavia, in: The Law in the Making. A Comparative Survey, PIZZORUSSO, Alessandro (ed.), Berlin 1988, 332-341. 
paper the latest version of a bill between the decision on the amendment motions and the final vote. The final wording of a law - which is to be promulgated - is only produced after the final vote. In some parliaments the sponsor of the bill has the right to decide about the amendment motions without involving the plenary session of the House, or even committees can only suggest amendments which are previously endorsed by the proponent, thus limiting the control of the full House over the bill.

Across the whole region numerous fast-track legislative procedures can be found. The criteria to use the fast track are not always clear, and can be interpreted subjectively. It is unfavourable that the basic legislative procedure is slow; there are too many opportunities for applying the fast-track solutions that restrict transparency and put the parliamentary opposition at a disadvantage. In Macedonia, especially until 2009, an extremely high share of laws was adopted in urgent procedures. In Serbia, the share of fast track laws varies year by year, but their share is always high: in the last 10 years, except for the year 2011, the share of laws adopted in urgent procedures was never below $30 \%$. In the Federation, the share of laws adopted on the fast track is also very high: it amounted to $85 \%$ in 2007 . The fast-track formula is applied by some of those parliaments to compensate for the time lost during political crises or because of the slowness of basic legislative procedure. Instead of being so lenient towards the fast-track solutions, it would be more purposeful making the basic procedure more effective and narrowing the scope of summary proceedings. As for the amendment of the constitution - which is a matter strictly within the competence of parliaments - it requires a special procedure, longer time limits and unquestionable majority requirements.

Although on paper the rules are in place to protect minority rights, they are often ignored: committees of inquiry are promised but never set up (Albania) or representatives of the government are not present in the legislative chamber during Question Time (Bosnia and Herzegovina). The questions put by MPs often remain unanswered and interpellations are few and far between. The findings of scrutiny are hardly incorporated into the parliaments' daily work. Overall, the practice and culture of parliamentary scrutiny of the Western Balkans are below democratic standards.

As for the legal status of MPs, the principle of free mandate can be found in the rules of several parliaments but in practice the political parties and their parliamentary groups often impede its exercise. In Serbia the parliamentary rules openly contradict the principle of free mandate. In each country of the region the right of immunity is assured yet those rules are rarely invoked: MPs' immunity is seldom suspended. In some of the countries under review the MPs are underpaid; it is not a requirement in each of the countries concerned to be a full-time MP. The MPs do not get an allowance to pay a retainer for experts and do not have parliamentary office space - so the conditions are not assured properly to exercise their rights as MPs.

The rules of each parliament include provisions about the transparency of legislative work but in practice that is restricted to the plenary sessions, which are generally open for the public in the whole region (however, a closed debate may be decided upon a simple majority vote). Committee sessions are not always open for the public, sometimes the openness depends on the decision of the committee chair. As a rule, public access is restricted to the verbatim minutes of the committee meetings. Many of the parliamentary documents 
(bills, amendments, committee reports, results of voting etc.) are available on parliamentary websites on the region, but a searchable database with a logical structure is missing. The publication of the voting results with the names of the MPs was started in 2014 in Republika Srpska, and it got major attention from the press and the public.

As far as the participation of the public in the law-making process is concerned, the possibility of citizens' legislative initiatives is widespread in the region (with rules requiring three thousand to thirty thousand signatures), yet there are only very few initiatives and only one or two laws in the entire region adopted by parliament upon a citizens' initiative. This form of citizen involvement has not been able to fulfil its task, and remained a possibility on paper only.

The possibility of an 'authentic interpretation', i.e. official statement of the parliament in the interpretation of a law in force, was in the past available in all former Yugoslav republics. This procedure is a leftover of the socialist period, when a strict separation of powers between the law-making legislative and interpreting judiciary was not foreseen. Parliament, as the supreme organ of people's representation, was entitled to interpret its own laws. However, this procedure was rarely used in regional practice. Parliaments normally chose to modify laws if problems occurred in their implementation instead of issuing an authentic interpretation. The interpretation of laws is the task of judges, and not of legally binding political decisions made by parliament. There are already signs of withdrawal of this procedure in the region: in Montenegro, the authentic interpretation procedure was deleted from the Rules of Procedure in 2010. In Albania, it was never introduced, and Kosovo as well avoided it when drafting its own RoP. On the other hand, in Serbia, Macedonia and the parliaments of Bosnia and Herzegovina, the procedure still exists, at least on paper. Macedonia is the only country where some authentic interpretation procedures still take place in practice. In Serbia, the procedure was launched for the last time in 2007, but saw a revival in 2013. In 2013, out of three initiatives, one was rejected and two adopted. In practice, however, the authentic interpretation, like legislative proposals, is prepared by the government services.

\section{Conclusion}

External powers have traditionally been playing a major role in solving internal conflicts of the Western Balkans; the history of that region has seen countless examples of limited sovereignty and the framing of constitutions under external pressure, ranging from the Congress of Berlin to Dayton and Kosovo. The public sphere teems with ethnic-based power sharing solutions in Bosnia and Herzegovina, Kosovo and, occasionally, Macedonia - which in some fields obstruct the democratic process. At times the ethnic composition of state bodies is predetermined (by quotas), and ethnic considerations are present in decision-making (dual vote) and in compensatory procedures (right of veto, the invocation of the so-called "vital national interest" procedure).

As a result, parliaments' work is formal, and generally unsatisfactory. Even if the written rules of parliamentary procedure are satisfactory, provisions of the constitution and the Rules of Procedure are not always implemented in practice. Formally, parliaments appropriately fulfil their role as legislative bodies. In some places legislative work is unduly slow 
and the outcome is uncertain (Bosnia and Herzegovina and the Federation of Bosnia and Herzegovina). European integration features high on the parliamentary agendas, and often that is used as a justification for fast-track legislative procedures. Less than optimal time and attention are devoted to legislative scrutiny and supervision of the work of the government. The opposition only has a limited say; and the culture of seeking consensus is underdeveloped. Transparency of legislation mainly applies to the deliberations of the plenary sessions. Only a part of the parliamentary documents is available for the public and, as a rule, they cannot be accessed online.

\begin{abstract}
The Western Balkans countries, yet differ in religious and ethnic background, their present-day constitutional setup - at least on paper - has plenty of similarities. Each of them has a parliamentary form of government, a proportional voting system, and a rather ceremonial head of state. Most of these countries have also a predominantly complex ethnic landscape. After the armed ethnic conflicts of the 1990s and 2000s, the region set out along constitutional consolidation. As a price of the peace, various ethnic-based power-sharing methods were introduced in the constitutional systems of the countries. However, this paper argues that any political regime based on such instruments - one that gives preference to the interests of certain ethnic groups - can only be built to the detriment of a democratic state. As a result of ethnic way of thinking, the political landscape is dominated by (mostly ethnic oriented) parties and effective decision-making procedures are often missing or neglected. Parliamentary activities are often held on a minimum scale, being based on obligatory tasks, a proactive manner (scrutiny, control of the government) is missing.
\end{abstract}

\title{
Keywords
}

Western Balkans, ethnic power-sharing, ethnic conflicts, parliamentary procedure

\section{References}

Albania 2012 Progress Report, European Commision, document SWD (2012) 334 final, Brussels 2012, online: https://ec.europa.eu/neighbourhood-enlargement/sites/near/files/ pdf/ key_documents/2012/package/al_rapport_2012_en.pdf.

BIEBER, Florian: Institutionalizing Ethnicity in the Western Balkans. Managing Change in Deeply Divided Societies, ECMI Working Paper No. 19, Flensburg 2004.

BIEBER, Florian: Power Sharing and International Intervention: Overcoming the Post-Conflict Legacy in Bosnia and Herzegovina, in: Settling Self-determination Disputes: Complex Power-sharing in Theory and Practice, WELLER, Marc - METZGER, Barbara (eds.), Leiden - Boston 2008, 193-241.

Bosnia and Herzegovina 2009 Progress Report, Commission of the European Communities, 
document SEC (2009) 1338, Brussels 2009, online: https://ec.europa.eu/neighbour hood-enlargement/sites/near/files/ pdf/key_documents/2009/ba_rapport_2009_en.pdf.

Bosnia and Herzegovina 2010 Progress Report, European Commission, document SEC (2010) 1331, Brussels 2010, online: https://ec.europa.eu/neighbourhood-enlargement/ sites/near/files/pdf/key_documents/2010/ package/ba_rapport_2010_en.pdf.

JOGAN, Savin: Some Specific Elements Concerning the Legislative Process of the S. F. R. of Yugoslavia, in: The Law in the Making. A Comparative Survey, PIZZORUSSO, Alessandro (ed.), Berlin 1988, 332-341.

MENDELSKI, Martin: Where does the European Union make a difference? Rule of law development in the Western Balkans and beyond, in: European Integration and Transformation in the Western Balkans. Europeanization or business as usual?, ELBASANI, Arolda (ed.), London 2013, 101-118.

PENEV, Slavica (ed.): Improving the process of economic reform legislation in Western Balkan countries, OECD Investment Compact for South East Europe, Belgrade 2009.

STOJANOVIĆ, Nenad-HODŽlĆ, Edin: Introduction: Ethnocracy at the Heart of Europe, in: Ethnopolitics, 14, 2015, 4, 382-389.

SZABÓ, Zsolt: The Parliamentary Legislative Process in the Accession Countries of the Western Balkans, in: Jahrbuch für Ostrecht, Vol. 2, 2015, 375-418.

SZABÓ, Zsolt: A Nyugat-Balkán parlamentjei, Budapest 2016. 